WISDOM: JURNAL PENDIDIKAN ANAK USIA DINI

Volume 02 No. 2 Desember 2021

\title{
PENANAMAN KARAKTER PEDULI LINGKUNGAN MELALUI PENGAJARAN FIKIH EKOLOGI PADA ANAK USIA DINI
}

\author{
M. Fathurahman \\ IAIN Ponorogo \\ Email: M.fathurahman85@gmail.com
}

\begin{abstract}
This research is a library research, with the title Cultivating Environmentally Concerned Characters through Teaching Ecological Jurisprudence in Early Childhood. This research uses library materials as the main data source, and the main references in this research are ecological and Islamic books, character education and books on early childhood. The purpose of this study is combining two materials at once, namely environmental figh material and its role in shaping the character of early childhood. The results showed. First, environmental damage or the current ecological crisis is not actually due to ecological succession factors. However, the damage occurred precisely because of an anthropogenic disaster by human activities. Second, in environmental figh it contains material that is very important to study, namely maqoshidu shari'ah, especially hifdzu al-bi'ah. Thirdly, environmental care character is very urgent, especially given to early childhood, and for now studying this section is an obligation.
\end{abstract}

Keywords: Ecological Jurisprudence, Environmental Care Character, Early Childhood

Abstrak: Penelitian ini merupakan penelitian kepustakaan (library research), dengan judul Penanaman Karakter Peduli Lingkungan Melalui Pengajaran Fikih Ekologi Pada Anak Usia Dini. Penelitian ini menjadikan bahan pustaka sebagai sumber data utama, dan acuannya adalah buku ekologi, keislaman, pendidikan karakter dan buku tentang anak usia dini. Tujuan dari kajian ini menggabungkan dua materi sekaligus yakni materi fikih lingkungan dan pembentukan karakter anak usia dini. Hasil penelitian menunjukkan. Pertama, kerusakan lingkungan atau krisis ekologi saat ini sejatinya bukanlah karena faktor suksesi ekologi. Namun kerusakan tersebut terjadi justru karena antropogenic disaster atau kerusakan yang disebabkan manusia. Kedua, dalam fikih lingkungan memuat materi yang sangat penting untuk dikaji yakni maqoshidu syari'ah utamanya hifdzu al-bi'ah. ketiga, karakter peduli lingkungan menjadi sangat urgen terlebih diberikan kepada anak usia dini, dan untuk saat ini mempelajari bagian ini sudah merupakan kewajiban.

Keywords: Fikih Ekologi, Karakter peduli lingkungan, anak usia dini

\section{PENDAHULUAN}

Fakta bahwa bencana di Indonesia secara umum disebabkan karena ulah manusia telah menemukan relevansinya. Pasalnya, sebagaimana dikabarkan bahwa akhir-akhir ini kebakaran yang melanda di sebagian 
M. Fathurahman, Penanaman Karakter Peduli Lingkungan Melalui Pengajaran Fikih Ekologi Pada Anak Usia Dini

wilayah di Indonesia memang ada unsur kesengajaan, baik yang dilakukan oknum korporasi ataupun yang lainnya. Bahkan sejak tanggal 9 Oktober 2019 BMKG mendeteksi peningkatan jumlah titik panas (hotspot) di beberapa wilayah Indonesia telah tercatat sebesar 1.547 titik. Titik panas tersebut berasal dari wilayah Sumatera Selatan, Kalimantan Tengah, Jambi dan Kalimantan Timur. ${ }^{1}$

Adapun berdasar data Badan Nasional Penanggulangan Bencana (BNPB) sampai Senin, 16 September 2019, pukul 16.00 WIB, titik panas ditemukan di Riau sebanyak 58, Jambi (62), Sumatera Selatan (115), Kalimantan Barat (384), Kalimantan Tengah (513) dan Kalimantan Selatan (178). Sementara luas karhutla di Indonesia selama 2019, sesuai data Kementerian Lingkungan Hidup dan Kehutanan (KLHK), sudah mencapai 328.722 hektare. Dari data itu, kebakaran di Kalimantan Tengah tercatat seluas 44.769 hektare, Kalbar (25.900 ha), Kalsel (19.490 ha), Sumsel (11.826 ha), Jambi (11.022 ha) dan Riau (49.266 ha). ${ }^{2}$

Masalah lingkungan hidup hingga saat ini -dalam bentuk apapunmemang banyak menuai perhatian masyarakat dunia, karena realitas mengatakan bahwa alam dari hari ke hari kian kritis. Hutan yang menyuplai oksigen kian hari kian menciut, air laut dan air sungai tercemar, tanah terkontaminasi zat-zat yang berbahaya, lapisan ozon semakin menipis dan menyebabkan panas yang sangat terasa, gumpalan gunung es di Kutub Utara dan Kutub Selatan mencair dan menyebabkan naiknya permukaan air

\footnotetext{
1Deputi Bidang Meteoroologi BMKG Mulyono Rahadi Prabowo dalam keterangannya, Selasa (15/10/2019). https://news.detik.com/berita/d-4746120/jumlah-hotspot-meningkat-bmkgimbau-masyarakat-waspada-karhutla. (diakses: 20/10/19).

2 Baca selengkapnya di artikel "Penyebab dan Akibat Kebakaran Hutan di Kalimantan Hingga Sumatera", https://tirto.id/eic3 (diakses: 20/10/19)
} 
WISDOM: JURNAL PENDIDIKAN ANAK USIA DINI Volume 02 No. 2 Desember 2021

laut. ${ }^{3}$ Seluruh fenomena ini dapat berakibat fatal bagi keberlangsungan semua spesies makhluk hidup di muka bumi.

Kejadian sebagaimana dipaparkan di atas lazim disebut sebagai bencana karena faktor antropogenik atau ulah manusia sendiri, baik karena kepentingan dirinya atau instansinya. ${ }^{4}$ Lebih lanjut, pemerhati lingkungan Wiryono mencatat bahwa akar permasalahan terkait lingkungan utamanya di Indonesia disebabkan oleh tiga alasan yakni gaya hidup, bertambahnya jumlah penduduk dan kemiskinan. ${ }^{5}$

Penulis akan menguraikan dari ketiganya, Pertama, gaya hidup yang darinya lahir anggapan bahwa manusia adalah the free and rational being (makhluk bebas dan rasional). Cara pandang ini keliru, karena memberikan legitimasi manusia untuk mengekploitasi alam. Artinya akar dari sumber krisis lingkungan disebabkan manusia dengan beragam keserakahannya. Lebih dari itu, gaya hidup yang identik dengan sikap eksploitatif ini juga mengancam keberadaan masyarakat tradisional yang sangat santun dalam memberlakukan lingkungan. ${ }^{6}$

Kedua, kerusakan lingkungan karena pertumbuhan penduduk. la menjadi kontribusi negatif yang mengancam lingkungan seperti perilaku destruktif keluarga yaitu limbah, pemanfaatan lahan, pembangunan rumah yang darinya menyumbang kerusakan alam. Ketiga, kerusakan lingkungan akibat kemiskinan. Fase kemiskinan menjadi alasan pembenar untuk

3 Nadjamuddin Ramly, Islam Ramah Lingkungan, Konsep dan Strategi Islam dalam Pengelolaan, Pemeliharaan, dan Penyelamatan Lingkungan, (Jakarta: Grafindo Khazanah IImu, 2007) hlm. 17

4 Sutopo Purwo Nugroho, BNPB(Badan Nasional Penanggulangan Bencana): Banyak Bencana yang disebabkan Manusia, (Republika.co.id, 05 Januari 2018)

5 Rifqiya Hidayatul Mufidah, Diskursus Pemikiran Fikih Lingkungan Ali Yafie dan Mujiono Abdillah, Supremasi Hukum, vol. 5 No. 1 (Juni 2016) 100

6 Dwi Runjani Juwita, Fiqh Lingkungan Hidup Dalam Perspektif Islam, El-Wasathiya Vol. 5 No. 1 Juni 2017, 28 
M. Fathurahman, Penanaman Karakter Peduli Lingkungan Melalui Pengajaran Fikih Ekologi Pada Anak Usia Dini

melakukan kegiatan yang mengancam eksistensi alam, mulaidari illegal logging (penebangan liar), pembakaran hutan untuk membuka lahan, namun abai terhadap resiko yang akan terjadi.

Ketiga permasalahan di atas dianggap sebagai penyumbang kerusakan alam paling nyata. Pendapat ini tidak berlebihan, bahkan sangat riil dan terjadi hingga hari ini. Namun demikian, terdapat keprihatinan yang mendalam apabila hal ini terjadi secara terus menerus sebab lambat laun dapat menghilangkan kemanfaatan dari alam itu sendiri, seperti berkurangnya pasokan oksigen, kurang maksimalnya penetralisir polusi udara hingga hilangnya potensi obat yang berasal dari alam. Dari sini, yang terancam bukan saja alam itu sendiri, namun juga manusia baik dewasa hingga anak-anak.

Oleh sebab itu, untuk memutus mata rantai ini, perlu kiranya memberikan pemahaman kepada anak-anak (anak usia dini) dengan harapan bahwa merekalah kelak yang akan mewarisi dan menghuni alam ini. Dengan adanya penyadaran itu kerusakan lingkungan di waktu yang akan datang dapat lebih bisa dikontrol dan diminimalisir. Pentingnya penanaman pengetahuan terkait lingkungan kepada anak usia dini, juga dapat dimaknai sebagai upaya strategis karena menyangkut pembentukan Sumber Daya Manusia yang lebih sadar terhadap lingkungannya.

Kelalaian tentang tugas ini, justru dapat menjadi embrio rusaknya alam secara kontinyu. Karena ibarat bangunan, anak usia dini adalah pondasi. Mengesampingkan kuatnya bangunan pondasi samahalnya membiarkan bangunan itu sewaktu-waktu akan roboh. Karenanya, menjadi signifikan kiranya bahwa penanaman tentang karakter peduli lingkungan kepada anak usia dini adalah jalan yang harus ditempuh sebagai upaya menyelamatkan bumi. 
Dalam perspektif Islam dalam hal ini fikih juga dibahas tentang pentingnya menjaga lingkungan. Karena itu, mengimplementasikannya pada tataran pendidikan anak usia dini merupakan langkah yang tepat untuk menanamkan karakter peduli lingkungan. Karenanya, cakupan penelitian ini tidak dapat dilepaskan dari matrifokus fikih lingkungan dan implementasinya terhadap pembentukan karakter peduli lingkungan yang diberikan anak usia dini.

\section{METODE PENELITIAN}

Penelitian ini menggunakan pendekatan deskriptif, yaitu berusaha menggali sedalam mungkin terhadap sumber-sumber yang dipergunakan. ${ }^{7}$ Selanjutnya, karena didasarkan pada data-data kepustakaan, maka penelitian ini dapat diklasifikasikan dalam penelitian kepustakaan (library research) yaitu telaah yang dilaksanakan untuk memecahkan suatu masalah yang pada dasarnya bertumpu pada penelaahan kritis dan mendalam terhadap bahan-bahan pustaka yang relevan. ${ }^{8}$

Penelitian ini menggunakan teknik literer, yaitu penggalian bahanbahan pustaka yang koheren dengan objek pembahasan yang dimaksud. ${ }^{9}$ Sedangkan Sugiono membahas akan teknik ini dengan istilah lain yaitu teknik dokumenter. ${ }^{10}$ Secara teknis dapat digambarkan sebagaimana berikut. Bahwa peneliti akan membaca referensi terkait, menguasai materi, menguasai metode, mencari dan menguasai data, menganalisa secara mendalam, melakukan perbaikan dan membuat kesimpulan.

\footnotetext{
${ }^{7}$ M. Nur Hakim, Metodologi Studi Islam (Malang: UMM Press, 2005), 84. 8 Jurusan Tarbiyah, Buku Pedoman Penulisan Skripsi (Ponorogo: STAIN Po Press, 2012), 61.

${ }^{9}$ Suharsimi Arikunto, Prosedur Penelitian Suatu Pendekatan Praktek (Jakarta: Rieneka Cipta, 1996),234.

10 Teknik dokumenter ialah mengumpulkan data dari berbagai dokumen yang dapat berbentuk tulisan, gambar atau karya monumental. Lihat: Sugiono, Metode Penelitian Pendidikan: Pendekatan Kuantitatif, Kualitatif dan R\&D (Bandung: Alfabeta, 2006), 329.
} 
M. Fathurahman, Penanaman Karakter Peduli Lingkungan Melalui Pengajaran Fikih Ekologi Pada Anak Usia Dini

Analisa pada penelitian ini menggunakan analisis isi (content analysis). Content analysis adalah setiap prosedur sistematis yang dirancang untuk mengkaji isi informasi terekam. ${ }^{11}$ Analisa data dilakukan dengan mengorganisasikan data, menjabarkannya ke dalam unit-unit, melakukan sintesa, menyusun ke dalam pola, memilih mana yang paling penting dan yang akan dipelajari, sehingga akan dapat membuat kesimpulan yang dapat diceritakan kepada orang lain. Content analysis ini nantinya untuk menganalisa penelitian peran Fikih Ekologi dalam upaya penanaman karakter peduli lingkungan pada anak. Dan hasil dari analisis ini adalah diperolehnya hasil dari penelitian yang dimaksud sekaligus tawaran implementasi dari fikih ekologi.

\section{KERANGKA TEORI}

\section{Pendidikan Karakter}

Mendapatkan pemahaman yang komprehensif terkait dengan karakter peduli lingkungan, maka sudah seharusnya didasari dulu dengan pemahaman pendidikan karakternya. Pendidikan karakter disini berfungsi untuk menghantarkan kepada pemahaman yang representatif dari ragam karakter itu sendiri, sebab karakter sendiri macamnya sangat banyak sekali, dan pendidikan karakter adalah asas fundamental sebelum karakter dikembangkan. Singkatnya pendidikan adalah wadah dari karakter itu sendiri.

Thomas Lickona berpendapat bahwa pendidikan karakter adalah pendidikan yang membentuk kepribadian seseorang melalui pendidikan budi pekerti dimana hasilnya adalah tindakan nyata baik dalam bentuk perilaku yang positif, jujur, bertanggungjawab, menghormati orang lain dan

11 Michael H. Walizer, Metode Penelitian Dan Analisis Penelitian, terj. Arief Sadiman (Jakarta: Erlangga, 1991), 48. 
sebagainya. ${ }^{12}$ Pendidikan karakter menjadi kebutuhan setiap manusia yang mendambakan kehidupan yang lebih positif, baik bagi guru sendiri lebih-lebih anak. Karakter dalam diri anak sudah pasti bergantung dari siapa yang mendidik dan menularkannya, sebab ia tidak serta merta lahir dengan sendirinya akan tetapi butuh dibiasakan bahkan dilatih agar semakin kuat.

Karenanya tidak salah jika Russel Williams beranggapan bahwa karakter diumpamakan sebagaimana otot yang akan menjadi lembek jika tidak dilatih secara teratur. Sebaliknya jika latihan demi latihan itu dilaksanakan maka akan menjadikan kuat dan proporsional. Gambaran karakter juga demikian, jika dibiasakan dan menjadi habit yang positif

Para pakar pendidikan pada umumnya berpendapat bahwa peningkatan pendidikan karakter lebih tepat jika dilakukan pada jalur pendidikan formal. Bahkan dalam pendekatan perkembangan karakter perlu mengadopsi cara-cara negara barat, seperti pendekatan moral kognitif, pendekatan analisis nilai dan klarifikasi nilai. Namun ada pula yang berpendapatan bahwa pendekatan yang dilakukan adalah pendekatan tradisional yakni penanaman nilai sosial pada diri anak.

Konsep pendidikan karakter utamanya karakter peduli lingkungan ini, terdapat beberapa poin penting tentang bagaimana pendidikan karakter tersebut dijalankan terutama kepada anak usia dini. Pertama, menjadikan materi tentang lingkungan sebagai salah satu kajian utama dalam pembelajaran anak usia dini. Kedua, menjadikan materi lingkungan setara dengan materi keagamaan, yang bukan saja selesai dihafalkan namun juga perlu dipraktikkan. Ketiga, menginternalisasikan materi lingkungan dengan

12 Heri Gunawan, Pendidikan Karakter Konsep dan Implementasi, (Bandung: Alfabeta, 2017) 23 
M. Fathurahman, Penanaman Karakter Peduli Lingkungan Melalui Pengajaran

Fikih Ekologi Pada Anak Usia Dini

materi apapun yang dikaji, baik di dalam kelas apalagi pembelajaran di luar kelas.

\section{Fikih Ekologi}

Untuk membangun landasan teori dalam penelitian tersebut, pertama penyusun akan menjelaskan tentang definisi umum tentang fikih lingkungan. Kata fikih (dalam bahasa Arab al-fiqh) berakar dari kata "faqiha-yafqihufiqhan" yang berarti al-fahmu (pemahaman). ${ }^{13}$ Sedangkan menurut istilah, fikih adalah ilmu pengetahuan tentang hukum (aturan) syara' yang bersifat praktis yang diambil dari dalil-dalil yang bersifat tafsili (terperinci). ${ }^{14}$

Al-Amidi seorang Fuqoha bermadzhab Syafi'l berpendapat bahwa fikih adalah ilmu tentang kumpulan hokum syara' furu'iyah dengan cara mencurahkan pemikiran dan istidlal. ${ }^{15}$ Dari pemahaman ini dapat diartikan bahwa fikih berarti produk yang dihasilkan dari melihat problematika keumatan, kemudian adanya kesesuaian dalil yang bersinggungan dengan kasus yang tengah terjadi tersebut. Atau dapat juga sebaliknya, nushush yang bersifat umum dari dua sumber baku (al-Qur'an dan Hadits) kemudian dipelajari dan dijadikan naungan apabila ditemukan kasus terkait fikih.

Setelah mendalami makna fikih secara komprehensif, selanjutnya penyusun akan menjabarkan tentang pengertian lingkungan, yang dalam bahasa kajian ilmu lingkungan disebut ekologi. Kata ekologi berasal dari kata Yunani Oikos yang berarti rumah tangga atau tempat hidup dan Logos yang berarti ilmu. ${ }^{16}$ Otto Soemarwoto mendefinisikan ekologi yakni ilmu tentang

13 Muhammad ibn Ya'kub al-Fayrus Abadi, Al-Qamus al-muhith (Beirut: Al-muassasah alRisalah, 2005) 1250

14 Jamaludin Ibrahim ibnu Hasan Al- Asnawi, Nihayatu al-wushul Fi Syarhi Minhaji al-Wushul ila ilmi al-Ushul, (Beirut: Dar Ibnu Hazm, 1999) 16

15 Lina Kushidayati, Agus Fakhrina, Iman Fadhilah, Pengembangan IImu Fikih Dalam Perspektif Filsafat Ilmu, Jurnal Yudisia, Vol. 5 No. 2 Desember 2014

16 Kaslan A. Tahir, Butir-butir Tata Lingkungan, (Jakarta: Rineka Cipta, 1991) hlm. 29 
hubungan timbal balik makhluk hidup dengan lingkungan hidupnya. ${ }^{17}$ Jadi, ketika terjadi permasalahan pada lingkungan hidup sejatinya adalah hilangnya kegiatan timbal balik itu sendiri.

Adapun secara etimologis, ekologi dapat dikembangkan artinya menjadi ilmu yang mempelajari tentang seluk beluk rumah tangga, termasuk di dalamnya proses dan pelaksanaan fungsi dan hubungan antar komponen secara keseluruhan. Sedangkan secara terminologis ekologi merupakan disiplin ilmu yang mempelajari tentang proses interelasi dan interdependensi antar organisme dalam satu wadah lingkungan tertentu secara keseluruhan.

Seorang pakar lingkungan yakni Imam Supardi mengatakan bahwa makna ekologi adalah ilmu yang mempelajari hubungan antar makhluk hidup sebagai kesatuan dengan lingkungannya, tentang struktur dan fungsi alam. ${ }^{18}$ Adapun yang dipelajari dari ekologi tersebut adalah berbagai hubungan antara populasi dan komunitas makhluk hidup dengan lingkungannya. Oleh karenanya, ilmu ini banyak mempelajari tentang aspek-aspek lingkungan dimana terjadi interaksi berbagai faktor dalam lingkungan, antara faktor satu dan lainnya.

Selanjutnya perihal fikih ekologi perlu penyusun jabarkan dengan meminjam konsepsi yang dibangun oleh Ali Yafie. ${ }^{19}$ Menurutnya, fikih lingkungan merupakan penjabaran tentang konsep jinayah dalam disiplin ilmu fikih. Lebih jelasnya lagi yaitu: 1) seperempat dari fikih adalah membahas ibadah, segala hal teknis peribadatan umat muslim dibahas dalam cakupan poin ini, seperti shalat, puasa, zakat dan haji. 2) Seperempat kedua dari fikih adalah muamalah (sosial), yakni arena fikih yang membahas tentang relasi

\footnotetext{
${ }^{17}$ Ahmad Suhendra, Menelisik Ekologis dalam Al-Qur'an, Esensia Vol. XIV No. 1 (April 2013) 64

18 Imam Supardi, Lingkungan Hidup dan Kelestariannya,(Bandung: PT. Alumni, 2003)

${ }^{19}$ Ali Yafie, Merintis Fiqh Lingkungan Hidup, (Jakarta: Ufuk Press, 2006) 293
} 
M. Fathurahman, Penanaman Karakter Peduli Lingkungan Melalui Pengajaran Fikih Ekologi Pada Anak Usia Dini

antar manusia. Dalam implementasinya dapat berupa muamalah adabiyah seperti toleransi, kejujuran dalam perkara bisnis dan lainnya. 3) Seperempat ketiga yakni munakahat (pernikahan), sangat gamblang pada arena ini hal yang dibahas oleh fikih yaitu tentang relasi suami istri, bahkan sebelum itu yakni tentang syarat rukun terkait ibadah pernikahan. 4) Seperempat yang terakhir yakni tentang jinayah (kriminalitas). Pada posisi inilah fikih lingkungan ditautkan. Karena perusakan lingkungan masuk kajian jinayah ini. Bahkan cukup banyak ayat maupun hadits yang membincang tentang pelarangan melakukan perusakan lingkungan. ${ }^{20}$

\section{a. Fikih Ekologi bagi Anak Usia Dini}

Memahami fikih terasa kurang lengkap jika hanya berhenti pada pemahaman hukum (yurisprudensi) yang bersifat hitam dan putih. Cara pandang demikian mengantarkan pada kesimpulan bahwa fikih seolah menjadi salah satu fan ilmu yang sangat rigit dan eksklusif. Jika fikih hanya dipahami sebatas ini, maka kesinambungan dengan ilmu lain menjadi terbatas.

Ali Yafie menuangkan konsepnya tentang betapa pentingnya kesadaran menjaga lingkungan sebagai sebuah tanggung jawab individu, sehingga manusia memiliki pilihan tanggung jawab agar tidak terjerumus dalam kategori pelaku jinayah. Pun demikian, sebenarnya kontekstualisasi figh al-bi'ah justru menyatukan dari empat unsur fiqih yang merupakan penjabaran ilmu fiqih. Dalam arti bahwa keempatnya (ibadah, muamalah, munakahat, jinayat) dapat untuk mengatasi problematika lingkungan hidup.

20 M Fathurahman, Ruliq S, Environmental Ethics in Ali Yafie's Perspective and its Significance for Environmental Conservation in Indonesia, Artikel dipresentasikan pada acara Ancoms di Surabaya 2019. 
Berikutnya ia memasukkan kategori menjaga lingkungan ini dalam aldhoruriyatul al-sittah (enam prinsip dasar kehidupan) sebagai bentuk penegasan tentang peran manusia dalam menjaga lingkungan. Enam prinsip ini harus benar-benar dijaga bahkan diperjuangkan, sebab salah satu dari keenamnya hilang maka kehidupan manusia tidak lagi ideal. Al-dharuriyat al-sittah berisi:

Pertama, hifdzu al-ddin (menjaga agama) sudah ghalib bagi pemeluk agama Islam untuk menjaga eksistensi agamanya dengan cara melakukan aturan yang ada dalam agama ini, ini adalah cara bagaimana seseorang menjaga agar agama yang ia peluk agar tetap eksis baik bagi diri maupun alam sekitarnya.

Kedua, hifdzu al-aql (menjaga akal) dapat diwujudkan dengan cara menjaga kewarasan berfikir, dengan banyak belajar, berdiskusi, berkumpul dengan para expert di bidangnya masing-masing. Hal ini dimaksudkan agar manusia dapat memberikan nutrisi bagi otak dan dapat dimanfaatkan dengan benar dan sesuai tuntunan agama.

Ketiga, hifdzu al-nafs (menjaga jiwa) bisa dipraktikkan melalui kehatian-hatian dalam banyak hal atau ringkasnya menjaga diri ini bisa dalam bentuk internal maupun eksternal. Internal misalnya mentradisikan suatu hal yang positif bagi dirinya seperti olah raga, makanan bergizi, tidak merokok, menjauhi narkoba dan hidup yang teratur dan terarah. Adapun eksternal adalah menjauhi dari potensi-potensi bahaya dari luar yang setiap saat dapat mengganggu keselamatan kita.

Keempat, hifdzu al-mal (menjaga kekayaan) fiqih juga mengatur bahwa dalam batas tertentu kita boleh mengumpulkan kekayaan bahkan mempertahankannya dari pihak luar yang hendak berlaku kejahatan kepada kita. Bahkan fikih melegitimasi memberikan pengamanan kepada harta itu 
M. Fathurahman, Penanaman Karakter Peduli Lingkungan Melalui Pengajaran Fikih Ekologi Pada Anak Usia Dini

sebagaimana kita menjaga jiwa kita. Hanya saja, fikih juga mengatur bahwa konsekuensi orang memiliki harta adalah mensedekahkan sebagian dari kekayaan itu.

Kelima, hifdzu al-nasl (menjaga keturunan) dapat dimaknai adanya perintah ilmu fikih dari hal yang paling mendasar yakni perintah pernikahan, memilih jodoh yang baik, sehingga kelak menurunkan keturunan yang berkualitas. Disamping itu, menjaga keturunan juga dapat diejawantahkan dengan memberikan pendidikan yang terbaikbagi keturunan atau generasi kelak. Inilah wujud menjaga keturunan baik dari sisi lahir maupun batin.

Keenam, hifdzu albi'ah (menjaga lingkungan) sudah jelas bahwa tugas ini berarti menjauhkan diri dari perilaku merusak terhadap lingkungan atau alam. Menjauhkan diri dari cara berfikir egosentris dan antroposentris yang hanya mementingkan diri sendiri dan melakukan kesewenang-wenangan terhadap lingkungan sekitar. Dengan kata lain hifdzu albi'ah adalah menjaga eksistensi lingkungan yang bobotnya tidak kalah dengan menjaga agama, akal, jiwa, kekayaan dan keturunan.

\section{b. Metode dalam Implementasi Fikih Ekologi untuk Anak Usia Dini}

Implementasi fikih ekologi merupakan makna sesungguhnya dari green education yang diharapkan tidak hanya bekerja dalam area wacana yang ujung-ujungnya hanya berkisar tentang hafalan dan kognisi semata. ${ }^{21}$ Akan tetapi implementasi ini adalah bentuk kepedulian terhadap lingkungan sebagai manifestasi rasa syukur atas karunia yang diberikan oleh Tuhan yakni lingkungan yang subur makmur kaya akan manfaat.

21 Masnur muslih, Pendidikan Karakter (Menjawab Tantangan Krisis Multidimensional) (Jakarta: Bumi Aksara: 2018) 210 
Adapun metode implemetasi sebagai cara membentuk karakter pada Anak Usia Dini (AUD) selanjutnya akan disebut dengan anak- agar peduli terhadap lingkungannya sebagaimana termaktub di bawah ini:

1) Sedikit teori ${ }^{22}$

Teori apapun akan menjadi using jika hanya berhenti pada ranah verbal saja. Jangkauannya menjadi tidak maksimal sebab hanya menjadi bahan ucapan yang nirfaidah. Apalagi jika diterapkan pada anak, yang secara psikologi lebih mudah meniru dari pada menyerap perkataan dari orang di sekitarnya. Karena itu, teori akan menjadi konkrit ketika sering dipraktikkan. Disamping itu, memiliki karakter bagi anak termasuk diantaranya karakter peduli lingkungan tidak diukur dengan berapa jam dalam sehari dia mendapatkan materi tentang lingkungan itu sendiri. Apalagi penyampaiannya dengan cara ceramah, maka akan kecil sekali harapannya anak paham dan mempraktikkan. Akan tetapi, seberapa sering anak itu diminta untuk mempraktikkan dari materi yang berkenaan dengan lingkungan, hal inilah yang akan membekas dalam diri anak usia dini.

2) Keteladanan

Siapapun orang dewasa yang berada di sekitar anak, sesungguhnya secara moral memiliki tugas yang sangat urgen. Sebab bukan saja orang tua yang dapat mempengaruhi anak meski boleh jadi dominan tetapi karena daya rekam anak sangat kuat dia bisa saja terpengaruh oleh siapapun personal yang berada di lingkarannya. Tidak terkecuali televisi, media sosial, game maupun perangkat elektronik lainnya. Menyadari hal ini, upaya paling urgen adalah memberikan keteladanan yang nyata di

22 Helmawati, Pendidikan Karakter Sehari-hari, (Bandung: Remaja Rosdakarya, 2017) 24 
hadapan anak. Demikian pula pada praktik-praktik kesadaran lingkungan yang akan menjadikan karakter itu melekat pada kebiasaannya. Bisa dikatakan keteladanan adalah contoh yang paling mudah diserap, karena anak merekam setiap jengkal sesuatu yang akan diberikan kepadanya.

3) Pembiasaan

Teori bukan berarti sama sekali tidak penting, itu tetap memiliki posisi penting sebagai upaya penyadaran dari sisi verbal. Akan tetapi ada cara yang penting berikutnya yakni pembiasaan. Agar bagaimana sebuah pelajaran menjadi tertanam dalam diri anak atau integral bahkan harapannya adalah masuk dalam alam bawah sadarnya adalah dengan kebiasaan yang dibutuhkan pembiasaan ekstra. Pembiasaan tidak lain tujuannya agar perilaku itu akan bersifat otomatis. Misalkan melihat sampah berserakan maka dengan sendirinya atau kesadarannya akan memungutnya dan ditaruh di tempat semestinya. Maka pembiasaannya ini juga perlu diawali dulu dengan peranan orang dewasa di sekitarnya. Pembiasaan yang langsung diserahkan kepada anak atau tanggung jawabnya tidak mungkin terjadi begitu saja tetapi harus dimulai dulu oleh orang dewasa.

4) Banyak motivasi

Sudah lazim dirasakan apabila semangat setiap orang terkadang fluktuatif. Pada saat mood bagus maka bisa jadi sangat bersemangat, akan tetapi jika mood buruk maka yang terjadi adalah sebaliknya yakni bermalas-malasan. Jika sudah dalam posisi seperti ini, tidak ada cara lain bagi orang dewasa memberikan suntikan motivasi bagi anaktersebut. Dengan harapan agar sianak kembali mengingat tugas atau pun kebiasaan yang sudah dilaluinya. Lebih tepat lagi motivasi itu ditunjang dengan praktik langsung dari sipemberi motivasi. 
5) Penegakan aturan yang konsisten

Dalam perjalanan memberikan materi dan motivasi tidak sedikit muncul kendala, baik dari internal anaksendiri maupun eksternal lingkungan yang melingkupi. Jika sudah demikian, misal sudah pada taraf melakukan kesalahan maka seorang pembimbing harus menjalankan aturan yang konsisten. Harapannya adalah sistem yang dibentuk agar dipatuhi oleh anak sehingga sistem kemudian memiliki wibawa dan berjalan secara ideal. Hal seperti ini lumrah, sebab hidup sendiripun memiliki jalur utama yang harus ditempuh. Keluar dari jalur berarti melakukan kesalahan. Karena itu, sudah semestinya aturan ditegakkan. Dalam lingkup lebih luas sekalipun, keteraturan memang perlu dilaksanakan tidak terkecuali alam raya ini. Satu hal tidak sesuai porsi maka kehancuran menjadi ancaman. Ini dapat diilustrasikan jika tahunya adalah menebang pohon karena keserakahan dan enggan melakukan penanaman ulang, maka yang niscaya terjadi adalah hutan yang gundul dan berpotensi, longsor, banjir dan kehilangan cadangan sumber air.

Maka pengajaran kepada anak tentang kepedulian lingkungan perluaturan yang konsisten, dengan harapan bahwa kesadaran itu akan benar-benar dilakukan bahkan jika perlu hingga mendarah daging. Jika sudah demikian, maka hasil yang diraihpun menjadi sangat optimal. Kendati begitu, tugas tentang penanaman karakter peduli lingkungan bagi anak usia dini tidak lantas berhenti di situ saja, namun masih perlu proses penguatan dari lingkungan keluarga dan masyarakat secara umum (kerjasama), sehingga upaya yang dilakukan oleh satuan pendidikan yang formal maupun non formal dapat berkesinambungan (long life education). 
Selain metode yang telah dibahas di atas, penulis juga perlu kiranya menghadirkan metode penanaman karakter milik Abdurrahman An-Nahlawi. ${ }^{23}$ Ragam metode berfungsi untuk menyelami kebiasaan anak usia dini yang bisa saja berbeda-beda. Logika sederhananya, jika kurang berhasil dengan metode satunya maka boleh menggunakan metode lainnya namun tujuannya tetap sama yakni agar karakter peduli lingkungan menjadi budaya dalam hidup seorang anak dari mereka kecil hingga dewasa. Metode penanaman karakter milik Abdurrahman An-Nahlawi adalah:

a. Metode Hiwar/percakapan

Metode ini digunakan karena hiwar atau dialog merupakan cara paling mendasar dalam member pemahaman kepada anak usia dini perihal pentingnya permasalahan tertentu. Tidak lain dalam konteks ini adalah karakter peduli lingkungan. Selain itu, hiwar dianggap sebagai upaya yang mampu melahirkan dampak pedagogis diantara dua pihak dan menguatkan ide yang hendak disampaikan.

b. Metode Qishah

Boleh jadi ada anggapan metode bercerita adalah metode yang lapuk termakan zaman (out of date), akan tetapi studi di lapangan menyatakan bahwa metode bercerita sangat tepat sekali bagi anak usia dini. Sebab, sejatinya dalam cerita itu ada pelajaran/misi yang akan disampaikan bahkan didoktrinkan. Edukasi melalui cerita justru mampu memberikan pengalaman unik bagi anak kecil yang akan diingatnya sampai dewasa. Setelahnya, tinggal conten ceritannya yang diganti hingga ditambahi, dengan tujuan tetap yaitu memberikan pemahaman tentang pentingnya peduli lingkungan.

23 Heri Gunawan, Pendidikan Karakter (Konsep dan Implementasi), (Bandung: Alfabeta, 2017), 89 
c. Metode Targhib dan Tarhib

Dalam bahasa yang lebih mudah dipahami targhib watarhib ini adalah reward and punishment yakni metode yang mengedepankan apresiasi dan sikaptegas. Sebab dalam diri anak tidak dapat sertamerta dilepaskan, apalagi mereka tengah berada masa perkembangan baik secara fisik maupun mental, sehingga kesalahan seringkali terjadi. Jadi pada saat anak berperilaku benar maka perlu seorang guru memberikan apresiasi kepada anak atas kebenaran yaitu, pesan moralnya adalah anak paham bahwa apa yang dilakukan adalah benar. Namun sebaliknya, bahwa guru juga perlu memberikan hukuman yang mendidik pada saat anak melakukan kesalahan harapannya adalah tidak lagi mengulangi hal yang sama disamping memberikan terapi jera kepada diri anak.

Keseluruh metode di atas penting disampaikan kepada anak dengan harapan mereka memahami betul tentang peduli lingkungan yang akan memberikan dampak positif kepadanya hingga dewasanya kelak. Cara-cara di atas sangat efektif dan sangat perlu digalakkan mengingat kepedulian pada lingkungan kini berangsur hilang. Justru ironisnya adalah sikap antroposentristik orang dewasa dengan segala kepentingannya yang bukan tidak mungkin ditiru seorang anak. Mata rantai ini perlu diputus dan dihilangkan, sebab menurut penulis jika hal ini sampai terjadi adalah tanda kiamat bagi bumi ini, generasi yang tercetak bukan generasi yang mencintai tempat hidupnya yang dipijak namun hanya akan berfikir bahwa akan menginginkan sesuatu dan dari bumi inilah segala sesuatu didapatkan, sebuah ironi yang sangat nyata. 
M. Fathurahman, Penanaman Karakter Peduli Lingkungan Melalui Pengajaran

Fikih Ekologi Pada Anak Usia Dini

\section{TEMUAN DAN PEMBAHASAN}

Di Indonesia, sejarah masa lampau telah mencatat bahwa krisis ekologi atau terancamnya keseimbangan hubungan antara manusia dan alam, disebabkan oleh faktor alam. Kehancuran ekosistem yang ada disebabkan karena keberadaan alam sendiri yang sering disebut dengan suksesi ekologi. Suksesi adalah penggantian komunitas biotik yang lama dengan komunitas biotik yang baru. Contoh dari krisis ekologi ini adalah letusan Gunung Tambora di Sumbawa NTB (1815), yang menewaskan 92.000 jiwa. Contoh lain adalah meletusnya gunung Krakatau tahun 1883 dan menewaskan 36.600.24 Artinya bahwa meletusnya gunung-gunung tersebut adalah siklus yang niscaya terjadi.

Lebih jauh lagi, di Indonesia pernah terjadi peristiwa fenomena super volcano yang menurut catatan sejarah 75.000 tahun yang lalu, bahkan peristiwa itu dianggap oleh para ahli geologi merupakan letusan api terbesar dua juta tahun terakhir. Peristiwa ini adalah awal mula terjadinya danau Toba di Sumatra Utara. Maka, boleh dikatakan bahwa peristiwa ini adalah peristiwa krisis ekologi terdahsyat di bumi.

Beberapa kasus di atas adalah sedikit kasus dari hancurnya tatanan ekologi di bumi ini. Tidak terhitung berapa banyak kasus serupa di belahan bumi yang lain. Disamping gunung meletus masih ada lagi peristiwa lain yang masuk kategori krisis ekologi yakni, gempa bumi, tsunami dan kebakaran hutan yang natural. Akan tetapi, krisis ekologi dewasa ini ironisnya secara umum disebabkan oleh perilaku manusia (antropogenic disaster). Jadi, posisi manusia benar-benar memiliki peranan inti dalam adanya krisis ekologi terkait. Disamping itu, adanya anggapan bahwa seluruh yang tersedia di

24 Ketut Prasetyo dan Hariyanto, Pendidikan Lingkungan Indonesia, (Dasar Pedagogi dan Metodologi), (Bandung: Remaja Rosdakarya: 2018) 4 
WISDOM: JURNAL PENDIDIKAN ANAK USIA DINI Volume 02 No. 2 Desember 2021

bumi ini adalah untuk dieksploitasi. Anggapan keliru ini, apalagi jika sudah menjadi mindset merupakan gerbang krisis ekologi yang lebih parah, yang nyata dan membahayakan.

Manusia dalam posisi ini sangat perlu memperhatikan beberapa hal krusial yang menurut penulis adalah penanda eksistensi tentang kediriannya sebagai manusia yang beradab. Tanggung jawab kemanusiaan ini idealnya benar-benar dilaksanakan dengan penuh kesadaran: 1) keseimbangan ekologi dan sumber alam, 2) kelangsungan dan kelestarian hidup manusia, 3) estetika dan efisiensi, 4) pemanfaatan untuk kesejahteraan manusia, 5) pelestarian lingkungan guna generasi berikutnya. ${ }^{25}$

Pada beberapa poin di atas artinya manusia memang memiliki hak untuk melakukan pemanfaatan atas hasil bumi ini, namun yang perlu diperhatikan adalah tugas setelahnya setelah penggunaan itu. ${ }^{26}$ Manusia harus menyadari benar bahwa ia makhluk sosial yang hidup dengan manusia lain bahkan habitat lain pula. Sehingga tidak diperkenankan melakukan eksploitasi dan hanya untuk kepentingan pribadi maupun kelompoknya. ${ }^{27}$ Disamping itu, ia juga harus memikirkan etika sekaligus estetika dalam penggunaan alam ini. Etika yang dimaksud adalah applied ethich (etika terapan) dimana nilai dari istilah ini adalah penghargaan terhadap alam dan keselarasan dengan alam. Adapun estetika adalah nilai keindahan natural

${ }^{25}$ Khaelany, Islam kependudukan dan lingkungan Hidup (Jakarta: Rineka cipta, 1996) 87

26 Dalam sudut pandang agama Islam (QS. 15:20) menyatakan bahwa manusia dengan segala keperluan hidupnya telah dicukupkan oleh Allah baik keperluan hidup yang terkandung di langit seperti matahari dll maupun yang berada di bumi, semuanya diberikan guna kepentingan dan kemudahan manusia.

${ }^{27}$ Merujuk pada UUD Pasal 33 (ayat 3) "bumi dan air dan kekayaan alam yang terkandung di dalamnya dikuasai oleh negara dan digunakan untuk sebesar-besar kemakmuran rakyat". Artinya, bahwa kekayaan alam ini dalam alokasinya haruslah tepat dan tidak dimonopoli. Jadi UU ini mengilhami bahwa keadilan sosiallah yang menjadi goal darinya. Bukan pemodal, pejabat hingga pemangku kepentingan tertentu. 
M. Fathurahman, Penanaman Karakter Peduli Lingkungan Melalui Pengajaran Fikih Ekologi Pada Anak Usia Dini

yang harus senantiasa diperhatikan, dilestarikan dan diposisikan sebagai sesuatu hal yang harus tampak akan keberadaannya.

Karenanya sangat tepat sebagaimana diungkapkan oleh Al-Gore bahwa resep menjaga eksistensi alam ini meski manusia melakukan pemanfaatan atasnya yakni, 1) reference, manusia memperoleh informasi yang dari kitab suci seyogyanya mampu membimbingnya untuk bertindak lebih bijak dalam ekplore hasil bumi, 2) respect, penghargaan kepada seluruh makhluk hidup, artinya tidak semena-mena dalam memperlakukkan orang lain, dalam hal ini lingkungan dan segala yang melekat dengannya, 3) Restrain, poinnya adalah prinsip tepat guna yakni bahwa bumi ini pada saat yang sama dapat dimanfaatkan namun juga penting untuk dikembangkan ulang agar hasilnya lebih optimal, 4) Redistribution, yakni dalam pemanfaatan lahan ada hak orang lain yang diperhatikan, atau alokasi lain dalam bingkai sosial, charity dan kegiatan positif dan produktif lainnya. 5) Responsibility, yakni sikap tanggung jawab merawat kondisi lingkungan se-detail mungkin guna memberikan hak akan lingkungan itu sendiri. ${ }^{28}$

Hanya saja, fakta di lapangan membuktikan bahwa krisis ekologi di Indonesia yang setiap saat bertambah prosentasenya. Lebih karena faktor human action (perbuatan manusia). Miller Jr, beranggapan bahwa oknum yang menyebabkan terjadinya krisis ekologi ini tidak lain karena oknum tersebut memiliki frontier mentality (mentalitas frontier). Maksud dari pernyataan ini adalah manusia dengan mental "buang apa saja", yakni manusia yang beranggapan bahwa bumi adalah ruang dan sumber daya yang tak terbatas. Dengan asumsi bahwa ia bisa melakukan apapun dengan sesuka hatinya. Seperti contoh, ia mengeksploitasi Sumber Daya Alam (SDA) yang ada, dan ketika habis ia pindah dari tempat itu. Membuat polusi di area

28 Lihat dalam Al-Gore, Bumi dalam Keseimbangan, Terj. Hira Jhamtani (Jakarta: Yayasan Obor Indonesia 1994) 243 
tertentu, setelah polusi cukup mengganggu maka ia pindah ke tempat baru dan melakukan hal yang sama dan seterusnya.

Senada dengan apa yang disampaikan Miller, Rene Descartes mengembangkan paradigma baru yang bersifat mekanistik reduksionis yakni penegasan posisi antara subyek dan obyek. Pada kasus ini dapat untuk membaca kasus ekologi dimana subyek dalam hal ini adalah manusia dan obyeknya adalah alam. Sehingga manusia memiliki peran utama dalam memposisikan dirinya dan apa yang ada di luar dirinya. Jadi, manusia sangat berhak untuk mendapatkan apa yang hendak diinginkan sekalipun sesungguhnya hal itu menimbulkan krisis ekologi yang tidak sepele.

Pengikut Kant John Rawhl, lebih gamblang lagi dalam mengidentifikasi hal tersebut. la berpandangan bahwa makhluk rasional "boleh" menguasai makhluk non rasional. Realitas alam dianggapnya berbeda dengan dirinya, sehingga di luar makhluk rasional (manusia) hanyalah pelengkap dan sarana untuk memenuhi kebutuhan. Karenanya, pendekatan ekologi seperti ini disebut dengan pendekatan antroposentrisme. Bahwa segala sesuatu bergantung pada bagaimana manusia sebagai pusatnya atau dengan kata lain manusia adalah aktor penentunya.

\section{KESIMPULAN}

Penanaman karakter peduli lingkungan pada anak usia dini, dapat diupayakan dengan cara menginternaslisasikan fikih ekologi dalam maqhasidu syari'ah. Keberadaannya menjadi warna khusus bahwa pentingnya menjaga pilar agama Islam tidak hanya berhenti pada maqhasidu syari'ah yang berjumlah lima, akan tetapi harus menyertakan hifdzul bi'ah yakni menjaga lingkungan dimana manusia hidup dan mengambil manfaat darinya. 
M. Fathurahman, Penanaman Karakter Peduli Lingkungan Melalui Pengajaran Fikih Ekologi Pada Anak Usia Dini

Sisi praktis fikih ekologi juga sangat mudah diterapkan, utamanya kepada anak usia dini. Jika sejauh ini anak usia dini mudah sekali menghafal dan mempraktikkan, praktik-praktik agama dalam kehidupan harian. Maka yang harus diperhatikan dalam memperlakukan lingkungan juga sama, yakni menganggap penting bahwa lingkungan adalah bagian tak terpisahkan dari manusia.

Selanjutnya, peran anak usia dini menjadi poin penting berikutnya sebab kepada merekalah kelak beban pelestarian alam ini dibebankan. Jika hal itu berjalan, maka dapat dipastikan bahwa alam akan tetap lestari, pemanfaatan dapat dibatasi dan eksploitasi alam dapat dihindari. Karenanya, fikih ekologi menjadi kunci penting atas lestarinya alam ini dan keberadaannya menjadi sebuah keharusan bagi penduduk bumi ini

\section{DAFTAR PUSTAKA}

Ade Fadli. Pendidikan Lingkungan Hidup: Bukan Untuk Pembebanan Baru Bagi Siswa. http://timpakul.web.id /plh-4.html

Cahyaningrum, E.S., Sudaryanti, Purwanto, N.A, (2017) Pengembangan Nilai-Nilai karakter Anak Usia Dini Melalui Pembiasaan dan Keteladanan, Jurnal Pendidikan Anak, 6 (2)

Djazuli dan Nurol Aen. 2000. Ushul Fiqh (Metodologi Hukum Islam), Jakarta: PT. Rajagrafindo

Dwi Purwati. 2017. Pendidikan Karakter Peduli Lingkungan dan Implementasinya. Dwijacendekia. 1 (2)

Fathurahman, M. 2016. Agama dan Ego Orang tua (Telaah Kritis atas Spontanitas Anak Dalam Pendidikan Keluarga), Jurnal Cendekia, $14(2)$

Ghufron, A dan Saharudin. 2007. Islam dan Konservasi Lingkungan (Telaah Pemikiran Fikih Lingkungan Yusuf al-Qaradhawi). Jurnal Millah. 6 (2)

Ghurfon, M. 2010. Fikih Lingkungan, Jurnal al-Ulum, 10 (1) 
H. De Vos. 2002. Pengantar Etika. Yogyakarta: Tiara Wacana

Hakim, M. N. 2005. Metodologi Studi Islam Malang: UMM Press

Imam Al-Qurtubi. Tafsir Al-Qurtubi. (Maktabah Syamilah)

Imam Asy-Saukani. Fathul Qodir. (Maktabah Syamilah)

Janet, Bock. 1992. The Young Child, Development From Pre-birth Trough Age Eight: New York, Maxwell Macmillian International

Juwita, D.R. 2017. Fiqh Lingkungan Hidup DalamPerspektif Islam. Jurnal ElWasathiya, 5 (1).

K. Bertens. 2007. Etik. Jakarta: PT Gramedia Pustaka Utama

Khalaf, A.W. 1978. IImu Ushul Alfiqh. Cairo: Dar Al-Qalam

Lina Kushidayati, Agus Fakhrina, Iman Fadhilah. 2014. Pengembangan IImu Fikih Dalam Perspektif Filsafat IImu, Jurnal Yudisia, Vol. 5 No. 2 Desember

Mohammad Soerjani. 2009. Pendidikan Lingkungan (Environmental Education, sebagai dasar sikap perilaku bagi kelangsungan hidup menuju pembangunan berkelanjutan), Jakarta: UI-Press

Mufid, S.A. 2010. Ekologi Manusia (Dalam Perspektif Sektor Kehidupan dan Ajaran Islam). Bandung: PT. Remaja Rosdakarya

Mufidah, R.H. 2016.Diskursus Pemikiran Fikih Lingkungan Ali Yafie dan Mujiono Abdillah,Jurnal Supremasi Hukum, 5 (1)

Munawir, dkk. 2005. Cakrawala Geografi 2. Bogor: Yudhistira

Purwanti, D. 2017. Pendidikan Karakter Peduli Lingkungan dan Implementasinya. Jurnal Dwijacendekia, 1 (2).

Rahmat. 2008. Implementasi Nilai-Nilai Islam Terhadap Pembinaan Kesadaran Lingkungan Hidup di Madrasah Aliyah Negeri Daerah Istimewa Yogyakarta" Yogyakarta: Program PascasarjanaUIN SunanKalijaga

Retno, Soetaryono. 1999. Aplikasi Pendidikan Lingkungan pada Jenjang Menengah, Makalah Lokakarya Penerapan Model Pendidikan Lingkungan Hidup di Sekolah, Bogor: IPB dan BPPT 
M. Fathurahman, Penanaman Karakter Peduli Lingkungan Melalui Pengajaran

Fikih Ekologi Pada Anak Usia Dini

Saleh, I.S. 2010. Islam dan Krisis Ekologi (Upaya Mengembangkan Pendidikan Islam Berbasis Lingkungan) dalambuku Islam National Character Building dan Etika Global, Yogyakarta: UIN SunanKalijaga

Septiana, R., Putri, R.I., Hartono, Y. 2017. Mengenal Ukuran dengan Pendekatan PMRI Pada Aspek Kognitif Pendidikan Anak Usia Dini, Jurnal Pendidikan Anak, 6 (2)

Sirry, M. A. 1995. Sejarah Fiqih Islam. Surabaya: Risalah Gusti.

Srihayati. 2007. IImu Pengetahuan Sosial Geografi untuk SMP dan MTs Kelas VIII. Jakarta: Erlangga

Sugiono. 2006. Metode Penelitian Pendidikan: Pendekatan Kuantitatif, Kualitatif dan R\&D, Bandung: Alfabeta.

Suhendra, A. 2013. Menelisik Ekologis dalam Al-Qur'an. Jurnal Esensia. 14(1)

Sutopo PurwoNugroho, BNPB: Banyak Bencana yang disebabkan Manusia. (Republika.co.id, 05 Januari 2018)

Suyadi dan Maulidya Ulfah. 2017. Konsep Dasar PAUD. Bandung: Remaja Rosdakarya

Tafsir, A. 2005. Ilmu Pendidikan dalam Perspektif Islam. Bandung: Remaja Rosdakarya.

Tahir, K. A. 1991. Butir-butir Tata Lingkungan, Jakarta: RinekaCipta.

Tarbiyah. 2012. Buku Pedoman Penulisan Skripsi. Ponorogo: STAIN Ponorogo Press

Tri Sunarsih. 2018. Tumbuh Kembang Anak. Bandung: Remaja Rosda karya

W.J.S. Poerwadarminta. 2007. Kamus Umum Bahasa Indonesia. Jakarta: Balai Pustaka.

Wahbah Zuhaili. Fiqh al-Islam waadillatuhu. (Maktabah Syamilah)

Walizer, M. H dan Arief Sadiman. 1991. Metode Penelitian Dan Analisis Penelitian. Jakarta: Erlangga. 